\title{
MUSIC STUDENTS' INTERCULTURAL SENSITIVITY TO DIFFERENT RELIGIOUS CONVICTIONS
}

\author{
Dr. Miomira M. Đurđanović, University of Niš, Faculty of Arts, Niš, Serbia \\ E-mail: miomiradjurdjanovic@yahoo.com \\ Dr. Sonja S. Cvetković, University of Niš, Faculty of Arts, Niš, Serbia \\ E-mail: cvetkos@mts.rs \\ MA Marija M. Đorđević, Music Theory and Pedagogy, Niš, Serbia \\ E-mail: djordjevicmarija1991@gmail.com
}

\section{A R T I C L E IN F O}

Original Research

Received: September, 29.2018.

Revised: October, 24.2018.

Accepted: November, 26.2018.

doi:10.5937/ijcrsee1803059D

UDK

316.644-057.875:2(497.11)

$378.147:: 78(497.11)$

Keywords:

interculturality,

education,

religion,

music,

music students.

\section{A B S T R A C T}

The authors' aim is to analyze the degree of openness to different religious convictions among students of Department of Music, Faculty of Arts in Niš, and also to test whether these students have an active attitude on overcoming religious prejudice. The research was initiated due to the fact that during their education, through various teaching activities (playing, singing, conducting, composition, listening to music and its analysis) students become familiar with religious, spiritual, and church music, as a constituent part of different religions. The assumption is that precisely through music as one of the most universal media of artistic communication students can establish and develop a positive attitude to religious differences. Research results show that students are aware of various religious convictions and affiliations, but they do not show enough sensitivity to respecting differences, and they do not take part in the struggle against prejudices that accompany those differences.

(c) 2018 IJCRSEE. All rights reserved.

\section{INTRODUCTION}

The connection between music and religion, which can be traced back to the very beginnings of human society and civilization, provides numerous opportunities for studying various aspects of their relationship and mutual influence. The study of these interactions is obviously quite inspirational because it has contributed to the establishment of a broad research domain, as testified by a huge number of papers dedicated to this topic (Begbie 2000; Yob 2010, 145-151; Hoffman 2011, 55-59; Westermeyer 2013, 567-583; Laack 2015, 220-246; Engelhardt and Bohlman 2016; MacInnis 2017, 51-64).

Each for itself, but also fused with one

Corresponding Author

Dr. Miomira M. Đurđanović, University of Niš, Faculty of Arts, Niš, Serbia

E-mail: miomiradjurdjanovic@yahoo.com

\section{cc) (†) $\ominus$}

This work is licensed under a Creative Commons Attribution - NonCommercial - NoDerivs 4.0. The article is published with Open Access at www.ijcrsee.com another, religion and music provide some of the key reference points around which collective and individual entities are formed; they represent powerful means of communication, venues of interlinking but also of putting up cultural barriers. An unavoidable segment of various religions and religious practices, music represents their recognizable aural symbol, and indirectly also a symbol of other identities, given the interpretation that precisely religious identity represents the core of ethnic and national identities. At the same time, regardless of the ways in which music interlinks with religion, and of the level to which music is subordinate to religious practice and religious canons, music in general, and thus also various forms of religious music - religious, spiritual, church/liturgical (Perković Radak 2006, 57-70; Prodanov 2007, 21-31; Marinković 2012, 61-72) possess universal properties which are not limited solely to the religious domain, but can act as an interlinking medium in the much broader domain of culture:

,If music is an integral part of what it is to be human, then it ought to reflect something of the image of God in 
which we are made. If part of the imago Dei is the relationship of love that lies at the heart of the Trinity, then perhaps music can open up a way of thinking about how we relate to the world and to God in a manner where love, rather than reason, dominates. After all, music is inherently relational, both internally in the way its notes are put together and externally in the way in which it is used to communicate in everyday life" (Chua, 2011, p.160).

Current processes of globalization and accelerated movement in time and space, caused by economic and migrations originating from wars and conflicts, have resulted, on the one hand, in the articulation of demands for an integrated society governed by a dialogue of cultures and the awareness of the need to acknowledge variety and specificities, but, on the other, in resistance to such demands in the form of the reactivation and enhancement of nationalism, religious intolerance, xenophobia, and racism. The concept of intercultural education, which puts an emphasis on intercultural communication and acquisition of intercultural competences, has derived precisely from the effort to reconcile and harmonize these opposing tendencies and thus enable the joint living of ethnic, national, and religious communities in the multicultural context, which has become one of the crucial characteristics of modern society (Campbell, 2002; Vidosavljević, Vidosavljević and Krulj Drašković, 2016).

The study of music students' intercultural sensitivity to different religious convictions was initiated due to the fact that during their entire education, through both their artistic and practical process (playing, singing, conducting, composing, listening to music) and scientific and theoretical educational process (history of music, music literature) students learn about the forms of religious, spiritual, and church (liturgical) music of numerous cultures and traditions - global, European, regional, national - covering various time periods and styles. Religious and spiritual music prevails in the curricula, but one should note that a certain number of students is actively involved in extracurricular activities - they sing in church choirs and thus participate in the service by performing liturgical music.

Yet, the obvious focus on the western European musical canon still prevails, and the study of the music of other cultures is more or less marginalized. For this reason, a more detailed analysis of conditions in the academic practice suggests that in the process of music education global educational requirements pertaining to the acquisition of knowledge and raising awareness on musical and cultural heterogeneity (religious, ethnic, linguistic) - are only partly met.

This research has been conducted precisely in order to analyze the degree of openness to different religious convictions among students of Department of Music, Faculty of Arts in Niš, and also test whether these students have an active attitude in the struggle against religious prejudice. Students of the Faculty of Arts in Niš represent a part of the ethnically and religiously homogeneous urban population of the second city in Serbia by size (about 250,000 inhabitants, according to the 2011 census), which has more than $90 \%$ Serbian population, the majority of whom are Christian Orthodox (Републички завод за статистику/Statistical Office of the Republic of Serbia, 2013). Niš Faculty of Arts also has students from other parts of Serbia, in which there is more ethnic and religious heterogeneity (north Serbia, Vojvodina), but their number is much lower. The second ethnic community by size in the city are Romanies (more than $5 \%$ ), while other ethnic communities do not exceed 1\% each (Републички завод за статистику/Statistical Office of the Republic of Serbia, 2013).

\section{MATERIALS AND METHODS}

The research was conducted on a sample selected from among students of the Faculty of Arts at the University of Niš $(\mathrm{N}=101)$. It was carried out in May, in academic 2016/2017. Participants were undergraduate students of the Music Theory and Pedagogy and the Performing Arts programs, and also graduate students of the Music Theory and Pedagogy program. Among them, most were second year students (30 or $29.7 \%)$, third year students (24 or $23.8 \%$ ), first year students (22 or $21.8 \%$ ), and finally fourth year students (15 or $14.9 \%$ ). The fewest students surveyed attended the master's program in Music Theory and Pedagogy $(10$ or $9.9 \%)$.

The research was based on the descriptive method. Surveying was used as a method to gather data. For this purpose, a previously constructed questionnaire was used (Dobrota 2016 , p. 209-218). In the first part, this instrument contains questions related to participants' sociodemographic data (type of studies, year of studies, and study program), while in 
the second it is based on The Munroe Multicultural Attitude Scale Questionnaire (Munroe and Pearson 2006) with three separate domains: knowledge/awareness, care/sensitivity, and acting/activity. Authors of this intercultural attitude questionnaire opined that proper assessment of the participant's condition in the three given domains would help establish an atmosphere that would be supportive in shaping intercultural attitudes.

The data obtained were processed in the IBM SPSS Statistics 23.0 software package. Descriptive statistics used included frequencies, percentages, means, and standard deviation. To reach statistically valid conclusions, the analysis used the non-parametric Chi square test, One-way ANOVA, and Paired Samples T-test.

\section{RESULTS}

\subsection{Knowledge/awareness of differences in religious convictions}

By means of the first research task we wished to examine how students perceived the position that religious convictions differ from one another. Students expressed their attitude by selecting one out of five claims offered ( $I$ do not agree at all - 1, I do not agree - 2, I neither agree nor disagree - 3, I agree - 4, I fully agree - 5).

Based on the obtained means $(\mathrm{M}=4.74$, $\mathrm{SD}=0.50$ ) we notice that students are quite aware and express a high degree of knowledge of the fact that religious beliefs differ. In fact, almost all participants $(97.0 \%)$ agree with the position that they are aware of religious differences. Of them, more than two thirds $(77.2 \%$ students) fully agree with the claim, while $19.8 \%$ express agreement. Only 3\% participants expressed indecision with regard to this claim (Table 1,2).

Table 1. Students' attitude on differences in religious convictions, by study program

\begin{tabular}{|c|c|c|c|c|c|}
\hline & $\begin{array}{l}\text { I neither } \\
\text { agree nor } \\
\text { disagree }\end{array}$ & $\begin{array}{c}\mathrm{I} \\
\text { agree }\end{array}$ & $\begin{array}{l}\text { I fully } \\
\text { agree }\end{array}$ & Total & \multirow{3}{*}{$\begin{array}{c}\mathrm{M}=4.74 \\
\mathrm{SD}=0.50 \\
\chi^{2}=3.499 \\
\mathrm{df}=2 \\
\mathrm{p}=0.174\end{array}$} \\
\hline $\begin{array}{c}\text { Music } \\
\text { Theory and } \\
\text { Pedagogy }\end{array}$ & $\begin{array}{c}2 \\
3.4 \%\end{array}$ & $\begin{array}{c}8 \\
13.6 \%\end{array}$ & $\begin{array}{c}49 \\
83.1 \%\end{array}$ & $\begin{array}{c}59 \\
100.0 \%\end{array}$ & \\
\hline $\begin{array}{l}\text { Performing } \\
\text { Arts }\end{array}$ & $\begin{array}{c}1 \\
2.4 \% \\
\end{array}$ & $\begin{array}{c}12 \\
28.6 \%\end{array}$ & $\begin{array}{c}29 \\
69.0 \%\end{array}$ & $\begin{array}{c}42 \\
100.0 \%\end{array}$ & \\
\hline Total & $\begin{array}{c}3 \\
3.0 \%\end{array}$ & $\begin{array}{c}20 \\
19.8 \%\end{array}$ & $\begin{array}{c}78 \\
77.2 \%\end{array}$ & $\begin{array}{c}101 \\
100.0 \%\end{array}$ & \\
\hline
\end{tabular}

Table 2. Students' attitude on differences in religious convictions, by year of studies

\begin{tabular}{|c|c|c|c|c|c|}
\hline & $\begin{array}{l}\text { I neither } \\
\text { agree nor } \\
\text { disagree }\end{array}$ & I agree & $\begin{array}{l}\text { I fully } \\
\text { agree }\end{array}$ & Total & \\
\hline \multirow{2}{*}{ First } & 0 & 4 & 18 & 22 & \multirow{6}{*}{$\begin{array}{l}\chi^{2}=7.337 \\
\mathrm{df}=8\end{array}$} \\
\hline & $0.0 \%$ & $18.2 \%$ & $81.8 \%$ & $100.0 \%$ & \\
\hline \multirow{2}{*}{ Second } & 1 & 6 & 23 & 30 & \\
\hline & $3.3 \%$ & $20.0 \%$ & $76.7 \%$ & $100.0 \%$ & \\
\hline \multirow{2}{*}{ Third } & 1 & 7 & 16 & 14 & \\
\hline & $4.2 \%$ & $29.2 \%$ & $66.7 \%$ & $100.0 \%$ & \\
\hline \multirow{2}{*}{ Fourth } & 1 & 0 & 14 & 15 & \multirow{4}{*}{$\mathrm{p}=0.501$} \\
\hline & $6.7 \%$ & $0.0 \%$ & $93.3 \%$ & $100.0 \%$ & \\
\hline \multirow{2}{*}{ Master } & 0 & 3 & 7 & 10 & \\
\hline & $20.0 \%$ & $30.0 \%$ & $70.0 \%$ & $100.0 \%$ & \\
\hline \multirow{2}{*}{ Total } & 3 & 20 & 78 & 101 & \\
\hline & $3.0 \%$ & $19.8 \%$ & $77.2 \%$ & $100.0 \%$ & \\
\hline
\end{tabular}

\subsection{Care for / sensitivity to the respect of different religions}

The second research task was to test students' attitudes on the respect of religious differences. The students expressed their attitude to the claim I am sensitive to the respect of various religions by selecting one out of five answers offered (I do not agree at all - $1, I$ do not agree - 2, I neither agree nor disagree - 3, I agree - 4, I fully agree - 5).

The means we obtained $(\mathrm{M}=3.00$, $\mathrm{SD}=1.23$ ) suggest that students are neutral in terms of care for respecting various religious convictions. This is the attitude of $35.6 \%$ participants. Full sensitivity to and care for the respect of different religions is reported by $13.9 \%$ students, while a bit more of them $18.8 \%$ - stated they felt a certain amount of sensitivity. Disagreement with the claim I am sensitive to the respect of various religions was expressed by $16.8 \%$ students circling number 2 on the Likert scale, and $14.9 \%$ students circling number 1 . We can conclude that most participants are undecided on the matter of care for respecting other religions $(35.6 \%)$. When one groups students' responses, one notices a similar number of those who are sensitive and express care for respecting various religious convictions $(32.7 \%)$ and those who do not express such care $(31.7 \%)$ (Table 3,4$)$.

Table 3. Students' attitude on respecting different religions, by study program

\begin{tabular}{|c|c|c|c|c|c|c|c|}
\hline & $\begin{array}{c}\text { I do not } \\
\text { agree at } \\
\text { all }\end{array}$ & $\begin{array}{c}\text { I do } \\
\text { not } \\
\text { agree }\end{array}$ & $\begin{array}{l}\text { I neither } \\
\text { agree nor } \\
\text { disagree }\end{array}$ & I agree & $\begin{array}{l}\text { I fully } \\
\text { agree }\end{array}$ & Total & \\
\hline $\begin{array}{l}\text { Music } \\
\text { Theory } \\
\text { and } \\
\text { Pedagogy }\end{array}$ & $\begin{array}{c}5 \\
8.5 \%\end{array}$ & $\begin{array}{c}12 \\
20.3 \%\end{array}$ & $\begin{array}{c}22 \\
37.3 \%\end{array}$ & $\begin{array}{c}10 \\
16.9 \%\end{array}$ & $\begin{array}{c}10 \\
33.9 \%\end{array}$ & $\begin{array}{c}59 \\
100.0 \%\end{array}$ & \multirow{3}{*}{$\begin{array}{l}\mathrm{M}=3.00 \\
\mathrm{SD}=1.23 \\
\chi^{2}=6.267 \\
\mathrm{df}=4 \\
\mathrm{p}=0.180\end{array}$} \\
\hline $\begin{array}{l}\text { Performing } \\
\text { Arts }\end{array}$ & $\begin{array}{c}10 \\
23.8 \%\end{array}$ & $\begin{array}{c}5 \\
11.9 \%\end{array}$ & $\begin{array}{c}14 \\
33.3 \%\end{array}$ & $\begin{array}{c}9 \\
21.4 \%\end{array}$ & $\begin{array}{c}4 \\
9.5 \%\end{array}$ & $\begin{array}{c}42 \\
100.0 \%\end{array}$ & \\
\hline Total & $\begin{array}{c}15 \\
14.9 \%\end{array}$ & $\begin{array}{c}17 \\
16.8 \%\end{array}$ & $\begin{array}{c}36 \\
35.6 \%\end{array}$ & $\begin{array}{c}19 \\
18.8 \%\end{array}$ & $\begin{array}{c}14 \\
13.9 \%\end{array}$ & $\begin{array}{c}101 \\
100.0 \%\end{array}$ & \\
\hline
\end{tabular}


Table 4. Students' attitude on respecting different religions, by year of studies

\begin{tabular}{|c|c|c|c|c|c|c|c|}
\hline & $\begin{array}{c}\text { I do not } \\
\text { agree at } \\
\text { all }\end{array}$ & $\begin{array}{c}\text { I do } \\
\text { not } \\
\text { agree }\end{array}$ & $\begin{array}{l}\text { I neither } \\
\text { agree nor } \\
\text { disagree }\end{array}$ & $\begin{array}{c}\text { I } \\
\text { agree }\end{array}$ & $\begin{array}{l}\text { I fully } \\
\text { agree }\end{array}$ & Total & \\
\hline First & $\begin{array}{c}7 \\
31,8 \%\end{array}$ & $\begin{array}{c}4 \\
18,2 \%\end{array}$ & $\begin{array}{c}7 \\
31,8 \%\end{array}$ & $\begin{array}{c}2 \\
9,1 \%\end{array}$ & $\begin{array}{c}2 \\
9,1 \%\end{array}$ & $\begin{array}{c}22 \\
100,0 \%\end{array}$ & \multirow{6}{*}{$\begin{array}{l}\chi^{2}=27.272 \\
\mathrm{df}=16 \\
\mathrm{p}=0.039\end{array}$} \\
\hline Second & $\begin{array}{c}3 \\
10.0 \%\end{array}$ & $\begin{array}{c}1 \\
3.3 \%\end{array}$ & $\begin{array}{c}17 \\
56.7 \%\end{array}$ & $\begin{array}{c}5 \\
16.7 \%\end{array}$ & $\begin{array}{c}4 \\
13.3 \%\end{array}$ & $\begin{array}{c}30 \\
100.0 \%\end{array}$ & \\
\hline Third & $\begin{array}{c}5 \\
20.8 \% \\
\end{array}$ & $\begin{array}{c}4 \\
16.7 \% \\
\end{array}$ & $\begin{array}{c}7 \\
29.2 \% \\
\end{array}$ & $\begin{array}{c}6 \\
25.0 \%\end{array}$ & $\begin{array}{c}2 \\
8.3 \%\end{array}$ & $\begin{array}{c}24 \\
100.0 \% \\
\end{array}$ & \\
\hline Fourth & $\begin{array}{c}0 \\
0.0 \%\end{array}$ & $\begin{array}{c}4 \\
26.7 \%\end{array}$ & $\begin{array}{c}3 \\
20.0 \%\end{array}$ & $\begin{array}{c}4 \\
26.7 \%\end{array}$ & $\begin{array}{c}4 \\
26.7 \%\end{array}$ & $\begin{array}{c}15 \\
100.0 \%\end{array}$ & \\
\hline Master & $\begin{array}{c}0 \\
0.0 \% \\
\end{array}$ & $\begin{array}{c}4 \\
40.0 \% \\
\end{array}$ & $\begin{array}{c}2 \\
20.0 \% \\
\end{array}$ & $\begin{array}{c}2 \\
20.0 \%\end{array}$ & $\begin{array}{c}2 \\
20.0 \%\end{array}$ & $\begin{array}{c}10 \\
100.0 \%\end{array}$ & \\
\hline Total & $\begin{array}{c}15 \\
14.9 \% \\
\end{array}$ & $\begin{array}{c}17 \\
16.8 \% \\
\end{array}$ & $\begin{array}{c}36 \\
35.6 \% \\
\end{array}$ & $\begin{array}{c}19 \\
18.8 \% \\
\end{array}$ & $\begin{array}{c}14 \\
13.9 \% \\
\end{array}$ & $\begin{array}{c}101 \\
100.0 \%\end{array}$ & \\
\hline
\end{tabular}

Table 5. Differences in attitudes to the respect of different religions, by year of studies

\begin{tabular}{ccccccc}
\hline \multirow{2}{*}{ Claim } & $\begin{array}{c}\text { Year of } \\
\text { studies }\end{array}$ & $\mathrm{N}$ & $\mathrm{M}$ & $\mathrm{SD}$ & $\mathrm{F}$ & $\mathrm{p}$ \\
\hline \multirow{2}{*}{$\begin{array}{c}\text { I am } \\
\text { sensitive to } \\
\text { the respect } \\
\text { of different } \\
\text { religions }\end{array}$} & First & 22 & 2.45 & 1.29 & & \\
\cline { 2 - 7 } & Second & 30 & 3.20 & 1.06 & & \\
\cline { 2 - 7 } & Fourth & 15 & 3.53 & 1.18 & & \\
\hline
\end{tabular}

\subsection{Students' activity in fighting against religious prejudice}

The third research question had the goal to determine how much students become involved in the struggle against religious prejudice, i.e. whether they actively oppose religious prejudice. In the survey, students were given an opportunity to use numbers from 1 ( $I$ do not agree at all) to 5 (I fully agree) so as to assess the degree to which they agree with the given claim.

The results we have obtained $(\mathrm{M}=3.91$, $\mathrm{SD}=1.05$ ) suggest that students do not actively participate in the struggle against religious prejudice. The claim I do not actively participate in the struggle against religious prejudice has received $36.6 \%$ responses showing full agreement, and $29.7 \%$ responses indicating agreement.

Table 6. Students' attitude on fighting religious prejudice, by study program

\begin{tabular}{|c|c|c|c|c|c|c|c|}
\hline & $\begin{array}{l}\text { I do not } \\
\text { agree at } \\
\text { all }\end{array}$ & $\begin{array}{l}\text { I do } \\
\text { not } \\
\text { agree }\end{array}$ & $\begin{array}{l}\text { I neither } \\
\text { agree nor } \\
\text { disagree }\end{array}$ & I agree & $\begin{array}{l}\text { I fully } \\
\text { agree }\end{array}$ & Total & \\
\hline $\begin{array}{l}\text { Music } \\
\text { Theory and } \\
\text { Pedagogy }\end{array}$ & $\begin{array}{c}0 \\
0.0 \%\end{array}$ & $\begin{array}{c}4 \\
6.8 \%\end{array}$ & $\begin{array}{c}18 \\
30.5 \%\end{array}$ & $\begin{array}{c}17 \\
28.8 \%\end{array}$ & $\begin{array}{c}20 \\
33.9 \%\end{array}$ & $\begin{array}{c}59 \\
100.0 \%\end{array}$ & \multirow{3}{*}{$\begin{array}{l}\mathrm{M}=3.91 \\
\mathrm{SD}=1.05 \\
\chi^{2}=6.088 \\
\mathrm{df}=4 \\
\mathrm{p}=0.193\end{array}$} \\
\hline $\begin{array}{l}\text { Performing } \\
\text { Arts }\end{array}$ & $\begin{array}{c}2 \\
4.8 \% \\
\end{array}$ & $\begin{array}{c}4 \\
9.5 \% \\
\end{array}$ & $\begin{array}{c}6 \\
14.3 \% \\
\end{array}$ & $\begin{array}{c}13 \\
31.0 \% \\
\end{array}$ & $\begin{array}{c}17 \\
40.5 \% \\
\end{array}$ & $\begin{array}{c}42 \\
100.0 \%\end{array}$ & \\
\hline Total & $\begin{array}{c}2 \\
2.0 \% \\
\end{array}$ & $\begin{array}{c}8 \\
7.9 \% \\
\end{array}$ & $\begin{array}{c}24 \\
23.8 \%\end{array}$ & $\begin{array}{c}30 \\
29.7 \%\end{array}$ & $\begin{array}{c}37 \\
36.6 \%\end{array}$ & $\begin{array}{c}101 \\
100.0 \%\end{array}$ & \\
\hline
\end{tabular}

Table 7. Students' attitude on fighting religious prejudice, by year of studies

\begin{tabular}{|c|c|c|c|c|c|c|c|}
\hline & $\begin{array}{c}\text { I do } \\
\text { not } \\
\text { agree } \\
\text { at all }\end{array}$ & $\begin{array}{l}\text { I do } \\
\text { not } \\
\text { agree }\end{array}$ & $\begin{array}{l}\text { I neither } \\
\text { agree nor } \\
\text { disagree }\end{array}$ & I agree & $\begin{array}{l}\text { I fully } \\
\text { agree }\end{array}$ & Total & \\
\hline First & $\begin{array}{c}1 \\
4.5 \%\end{array}$ & $\begin{array}{c}2 \\
9.1 \%\end{array}$ & $\begin{array}{c}5 \\
22.7 \%\end{array}$ & $\begin{array}{c}6 \\
273 \%\end{array}$ & 8 & 22 & \multirow{6}{*}{$\begin{array}{l}\chi^{2}=12.482 \\
\mathrm{df}=16 \\
\mathrm{p}=0.710\end{array}$} \\
\hline Second & $\begin{array}{c}1 \\
3.3 \% \\
\end{array}$ & $\begin{array}{c}4 \\
13.3 \%\end{array}$ & $\begin{array}{c}7 \\
23.3 \%\end{array}$ & $\begin{array}{c}10 \\
33.3 \%\end{array}$ & $\begin{array}{c}8 \\
26.7 \%\end{array}$ & $\begin{array}{c}30 \\
100.0 \%\end{array}$ & \\
\hline Third & $\begin{array}{c}0 \\
0.0 \%\end{array}$ & $\begin{array}{c}2 \\
8.3 \%\end{array}$ & $\begin{array}{c}3 \\
12.5 \%\end{array}$ & $\begin{array}{c}6 \\
25.0 \%\end{array}$ & $\begin{array}{c}13 \\
54.2 \%\end{array}$ & $\begin{array}{c}24 \\
100.0 \%\end{array}$ & \\
\hline Fourth & $\begin{array}{c}0 \\
0.0 \%\end{array}$ & $\begin{array}{c}0 \\
0.0 \%\end{array}$ & $\begin{array}{c}5 \\
33.3 \%\end{array}$ & $\begin{array}{c}4 \\
26.7 \%\end{array}$ & $\begin{array}{c}6 \\
40.0 \%\end{array}$ & $\begin{array}{c}15 \\
100.0 \%\end{array}$ & \\
\hline Master & $\begin{array}{c}0 \\
0.0 \%\end{array}$ & $\begin{array}{c}0 \\
0.0 \%\end{array}$ & $\begin{array}{c}4 \\
40.0 \%\end{array}$ & $\begin{array}{c}4 \\
40.0 \%\end{array}$ & $\begin{array}{c}2 \\
20.0 \%\end{array}$ & $\begin{array}{c}10 \\
100.0 \%\end{array}$ & \\
\hline Total & $\begin{array}{c}2 \\
2.0 \% \\
\end{array}$ & $\begin{array}{c}8 \\
7.9 \% \\
\end{array}$ & $\begin{array}{c}24 \\
23.8 \%\end{array}$ & $\begin{array}{c}30 \\
29.7 \% \\
\end{array}$ & $\begin{array}{c}37 \\
36.6 \% \\
\end{array}$ & $\begin{array}{c}101 \\
100.0 \%\end{array}$ & \\
\hline
\end{tabular}

\section{DISCUSSION}

Our research has studied students' knowledge/awareness of there being different religions, their care for/sensitivity to respecting different religions, and activity with the purpose of preventing religious prejudice.

The analysis of awareness of differences in religious beliefs (the attitude of awareness that there are different religious beliefs) by the study program (Table 1) shows that most students of the study program in Music Theory and Pedagogy $(83.1 \%)$ fully agree with this claim, i.e. they express a high degree of awareness of religious differences. Unlike this group, a bit fewer students of the study program in Performing Arts fully agree with our claim $(69.0 \%)$. Agreement with this attitude was expressed by $28.6 \%$ students of this study program. However, these differences between students of the two programs did not reach statistical significance $\left(\chi^{2}=3.499 ; \mathrm{df}=2\right.$; $\mathrm{p}=0.174$ ).

One reads from Table 2 that there are no significant differences in the awareness of religious differences among students of various years in the Faculty of Arts in Niš. We may claim that students of all years of undergraduate and graduate studies fully understand that there are differences in religious beliefs. Although the highest agreement with the claim was given by 4 th year students $(93.3 \%)$, differences in attitudes are minimal, as also testified by the results of the Chi-square test $\left(\chi^{2}=7.337\right.$, $\mathrm{df}=8, \mathrm{p}=0.501)$, showing no statistically significant differences.

By analyzing student's responses based on the study program (Table 3 ) one notices that there are only minimal differences in attitudes on the respect of different religions. Students of both programs are mostly undecided in terms of their care for the respect of different religious convictions. Although one 
may notice minimal differences in positions, results of the Chi-square test suggest that they are not statistically significant $\left(\chi^{2}=6.267\right.$; $\mathrm{df}$ $=4 ; \mathrm{p}=0.180$ ).

Results of the Chi-square test $\left(\chi^{2}=27.272\right.$, $\mathrm{df}=16, \mathrm{p}=0.039$ ) show a statistically significant difference in the attitude on the respect of different religions based on the year of studies. By analyzing Table 4 we find that first year undergraduates show the least sensitivity to the respect of different religious convictions $(50.0 \%)$. In the second undergraduate year, students are undecided $(56.7 \%)$, while in the third year responses are evenly distributed. Responses given by fourth year undergraduates suggest that these participants express care for and sensitivity to the given claim (53.4\%), while master students' responses are evenly distributed. We may say that, as they progress from lower to higher years of their studies, students become more careful of and sensitive to respect of different religions.

Measured by the ANOVA test, differences in the attitude on respecting different religions based on the year of studies remain at the borderline of statistical significance $(\mathrm{F}=2.259, \mathrm{p}=0.068)$. A post-hoc test revealed a significant difference between the first $(\mathrm{M}=2.45, \mathrm{SD}=1.29)$ and fourth year of studies $(\mathrm{M}=3.53, \mathrm{SD}=1.18)$, regarding the attitude to the claim I am sensitive to the respect of different religions (Table 5).

The results of this research show that $66.3 \%$ participants are not active in the fight against religious prejudice in any way. A neutral attitude to this claim has been expressed by $23.8 \%$ students, while $7.9 \%$ of participants disagree. Full disagreement with the given claim has been expressed by merely $2.0 \%$ participants. Based on all these facts, we can claim that only $9.9 \%$ students are actively involved in the struggle against religious prejudice.

By crosstabulating responses to the question about participation in the struggle against religious prejudice with the study program (Table 6), we obtained results suggesting that attitudes of students of Music Theory and Pedagogy on the one hand and Performing Arts on the other differ only minimally. A more prominent difference has been noted with regard to the position I neither agree nor disagree, which was selected by $30.5 \%$ students of Music Theory and Pedagogy and 14.3\% students of Performing Arts. By analyzing the responses, one may conclude that students of Music Theory and Pedagogy presented a more neutral attitude than students of Performing
Arts. The minimal differences are reflected in the result of the Chi-square test $\left(\chi^{2}=6.088, \mathrm{df}\right.$ $=4, p=0.193)$, which does not provide statistical significance for the differences noted.

Analysis of students' attitudes viewed against the year of their studies (Table 7) shows that all students have a similar attitude to becoming involved with the struggle against religious prejudice. The least active are thirdyear undergraduates, who do not act against religious prejudice in as many as $79.2 \%$ cases. Chi-square test shows no statistically significant differences among the year of studies in terms of struggle against religious prejudice $\left(\chi^{2}=12.482, \mathrm{df}=16, \mathrm{p}=0.710\right)$.

Our research has studied students' knowledge/awareness of there being different religions, their care for/sensitivity to respecting different religions, and activity with the purpose of preventing religious prejudice. Based on the $\mathrm{t}$-test results $(\mathrm{t}=13.01, \mathrm{df}=100$, $\mathrm{p}=0.000$ ) one can conclude that students are highly aware of the existence of different religious convictions $(M=4.74)$, yet they are not sufficiently sensitive to the respect of those differences $(M=3.00)$. Moreover, t-test results $(t=7.22, \mathrm{df}=100, \mathrm{p}=0.000)$ suggest that although students are aware of religious differences $(M=4.74)$, they do not become actively involved in the struggle against prejudice emerging from those differences $(M=3.91)$.

\section{CONCLUSION}

Based on the results of the study we have conducted, we have partly corroborated that students of the Faculty of Arts are open to different religious convictions. We have found that, as they progress toward the higher years of studies, students increase their care for and sensitivity to the respect of different religions. At the same time, results show that students very rarely become involved in the struggle against prejudice that accompanies religious differences.

Having in mind the fact that in music education there is a general focus on the study of western European art music, one needs to create conditions for the affirmation and study of music from other cultures, including familiarization with their musical characteristics. The occasional attempts made in this direction so far, aiming to enrich the study programs and the music education process in general with global educational trends to continually add new musical idioms to the study programs, cannot provide the proper basis for 
raising awareness on musical and cultural (religious, ethnic, linguistic) heterogeneity. In order to properly recognize, understand, and value the quality of the music of other nations, students of all study programs need to partake in various forms of the teaching process (playing, singing, conducting, composing, listening to music, music analysis) so as to become directly and actively familiar with the religious, spiritual, and church music of different religions. Such a teaching process would contribute to the emergence of an appropriate background for the acceptance of new values, and thus support the development of intercultural sensitivity, which would include the much needed interdisciplinary approach and critical reflection on the part of the students.

\section{ACKNOWLEDGEMENTS}

The paper is the part of the project of Niš Branch of the Serbian Academy of Sciences and Arts (SASA): 0-10-17 "The Music Heritage of Southeast Serbia, Contemporary Creativity and the Formation of Taste".

\section{Conflict of interests}

The authors declare no conflict of interest.

\section{REFERENCES}

Begbie, J. (2000). Theology, Music and Time. Cambridge: Cambridge University Press. https://books.google.rs/books?redir esc $=\mathrm{y} \& \mathrm{hl}=\mathrm{sr} \& \mathrm{id}=\mathrm{do} 4 \mathrm{~A} 0 \mathrm{xMyLk} 4 \mathrm{C} \& \mathrm{q}=$

Campbell, P. S. (2002). Music Education in a Time of Cultural Transformation. Music Educators Journal, 89(1), 27-32. https://doi. org/10.2307/3399881

Chua, D. (2011). Music as the Mouthpiece of Theology. In: Begbie, J. S. \& Guthrie, S. R. (Eds.): Resonant Witness. Conversations between Music and Theology. Grand Rapids: Eerdmans (137-160). https://books.google.rs/books?hl=en\&lr=\&id= vPh3k3cdrnoC\&oi $=$ fnd \&pg $=$ PR $8 \&$ dq $=$ Begbi $\mathrm{e},+\mathrm{J} .+\mathrm{S} .+\% 26+$ Guthrie $,+\mathrm{S} .+\mathrm{R} .+($ Ed. $):+$ Reson ant + Witness. + Conversations + between + Music +and+Theology.+Grand+Rapids:+Eerdmans + $(137 \% \mathrm{E} 2 \% 80 \% 93160) . \&$ ots $=$ BitTrWfLj\&si $\mathrm{g}=$ M1j0zEK32kvQYR7gZ5XȲgLqrSsw\&red ir_esc $=\mathrm{y} \# \mathrm{v}=$ onepage $\& \mathrm{q} \& \mathrm{f}=$ false

Dobrota, S. (2016). Povezanost između interkulturalnih stavova studenata i preferencija glazbi svijeta [The Relationship Between Students' Intercultural Attitudes and World Music Preferences]. Život i škola: časopis za teoriju i praksu odgoja $i$ obrazovanja, 62(1), 209-218. http://hrcak. srce.hr/index.php?show $=$ clanak\&id_clanak jezik $=243558$

Engelhardt, J. \& Bohlman, P. (Eds.). (2016). Resound- ing Transcendence: Transition in Music, Religion and Ritual. New York: Oxford, Oxford University Press. https://books.google.rs/books $? \mathrm{id}=\mathrm{bCx} 2 \mathrm{CwAAQBAJ} \& \mathrm{pg}=\mathrm{PA} 255 \& \mathrm{dq}=$ Enge lhardt, + J.+\%26+Bohlman, + P. $+($ Eds. $) .+(2016)$. + Resounding+Transcendence:+Transition+in+ Music, + Religion + and + Ritual. + New + York: $+\mathrm{O}$ $\mathrm{x}$ ford, + Oxford + University + Press. $\& \mathrm{hl}=\mathrm{sr} \& \mathrm{sa}=$ X\&ved=0ahUKEwisnL m26veAhVC2SwKH SBnAtUQ6AEIKDAA\#v $=$ onepage\&q=Engelh ardt $\% 2$ C $\% 20 \mathrm{~J} . \% 20 \% 26 \% 20$ Bohlman $\% 2 \mathrm{C} \% 20$ P.\%20(Eds.).\%20(2016).\%20Resounding\%20 Transcendence $\% 3 \mathrm{~A} \% 20$ Transition $\% 20$ in $\% 20$ Music\%2C\%20Religion\%20and\%20Ritual. $\% 20 \mathrm{New} \% 20$ York $\% 3 \mathrm{~A} \% 20$ Oxford $\% 2 \mathrm{C} \% 20$ Oxford $\% 20$ University $\% 20$ Press.\&f=false

Hoffman, A. (2011). Rethinking Religion in Music Education, Music Educators Journal, 97(4), 55-59. http://www.jstor.org/stable/23012617

Laack, I. (2015). Sound, Music and Religion: A Preliminary Cartography of a Transdisciplinary Research Field, Method \& Theory in the Study of Religion, 27(3), 220-246. https://doi. org/10.1163/15700682-12341339

MacInnis, J. (2017). Teaching Music in the Reformed/ Calvinist Tradition: Sphere Sovereignty and the Arts, Religions, 8(4), 51-64. https://doi. org/10.3390/rel8040051

Маринковић, Т. М. (2012). Религиозна, духовна, црквена музика - три Богонадахнута лица музике [Marinković, T. M.: Religious, spiritual, church music - three faces of music inspired by God], in: Каначки, В. \& Пајић, C. (Ed.): Језик музике. Музика и религија \& Реч и слика. Иконографије и иконографски метод - теорија и примена. Српски језик, књижевност, уметност, зборник радова са VI међународног научног скупа. Крагујевац: Филолошко-уметнички факултет (61-72). http://www.filum.kg.ac.rs/dokumenta/izdavastvo/zbornici/2012\%20Zbornik\%20VI\%20veliki\%20skup\%202011\%20knjiga3.pdf

Munroe, A. \& Pearson, C. (2006). The Munroe Multicultural Attitude Scale Questionnaire: A New Instrument for Multicultural Studies. Educational and Psychological Measurement, 66(5), 819-834. https://doi.org/10.1177/0013164405285542

Perković Radak, I. (2006). Muzika i pravoslavno bogosluženje. Pitanje termina [Music and Ortodox Service. Question of Terminology], in: Jeremić Molnar, D. \& Stamatović, I. (Eds.): Muzikološke $i$ etnomuzikološke refleksije. Beograd: Fakultet muzičke umetnosti (57-70). https://belgradeconference. katedrazamuzikologijufmu.net/wpcontent/uploads/2018/07/muz_i_etno_refleksije.pdf

Prodanov, I. (2007). Muzika izme $\bar{u}$ ideologije i religije [Music between ideology and religion]. Novi Sad: Stylos. https://books.google.rs/books?id $=$ xkaxGAAACAAJ\&dq=Prodanov+Ira+Muzi $\mathrm{ka}+\mathrm{izme} \% \mathrm{C} 4 \% 91 \mathrm{u}+\mathrm{ideologije}+\mathrm{i}+$ religije $\& \mathrm{hl}=\mathrm{s}$ $\mathrm{r} \& \mathrm{sa}=\mathrm{X} \& \mathrm{ved}=0$ ahUKEwiku7-a3KveAhXBWS wKHW6iAhAQ6AEIKDAA

Видосављевић, С., Видосављевић, М. \& Круљ Драшковић, J. (2016). Интеркултурална настава у васпитно-образовном процесу [Vidosavljević, S., Vidosavljević, M. \& Krulj Drašković, J.: Intercultural teaching in the Educational Process]. Зборник радова Учитељског факултета Призрен-Лепосавић, 10, 185-201. 
Miomira M. Đurđanović et al. (2018) - Music students' intercultural sensitivity to different religious convictions International Journal of Cognitive Research in Science, Engineering and Education (IJCRSEE), 6(3), 59-65

DOI:10.5937/zrufpl1610185V, https://scindeksclanci.ceon.rs/data/pdf/1452-9343/2016/145293431610185V.pdf

Републички завод за статистику [Statistical Office of the Republic of Serbia]. Попис становништва, домаћинстава и станова 2011. у Републици Србији - вероисповест, матерњи језик $u$ национална припадност, подаци по општинама и градовима [2011 Census of Population, Households and Dwellings in the Republic of Serbia - Religion, Mother Tongue and Ethnicity, Data by Municipalities and Cities]. (2013). http://pod2.stat.gov.rs/ObjavljenePublikacije/Popis2011/Knjiga4Veroispovest.pdf

Westermeyer, P. (2013). Music and Spirituality: Reflections from a Western Christian Perspective, $R e$ ligions, 4(4), 567-583. https://doi.org/10.3390/ rel4040567

Yob, I. (2010). Why is Music a Language of Spirituality? Philosophy of Music Education Review, 18(2), 145-151. https://doi.org/10.2979/ pme.2010.18.2.145 